историческое, типологическое и сопоставительное языкознание»; Волгоград, 2006. 23 с.

5. Dijk van Teun A. Cognitive and conversational strategies in the expression of ethnic prejudice. Interdisciplinary Journal for the Study of Discourse. Vol. 3. Issue 4. Amsterdam : Mouton Publishers, 1983. P. 375-404.

6. FlirtCafe. Das Single Portal für Flirten, Dating und Kontaktanzeigen für Singles. URL: http://www.flirtcafe.de

7. Kalishchuk D. Psycholinguistic Methods of Suggestion Strategies Realization as US Presidents' G. Bush Jr. and B. Obama Conceptual Style Markers. Psycholinguistics, 23(2), 2018. 107-119. URL: https://doi.org/10.5281/zenodo.1199146

8. Kerckhoff Alan C., Davis Keith E. Value consensus and need complementarity in mate selection. American sociological review. Vol. 27. 1962. pp. 295-303. URL: https://doi.org/10.2307/2089791

9. Neu.de. URL: http://www.neu.de/

10. Quoka.de URL: http://www.quoka.de/bekanntschaften/partnerschaften-kontakte/kleinanzeigen.html

11. SüddeutscheZeitung. URL: http://anzeigen-suchen.sueddeutsche.de/

DOI https://doi.org/10.30525/978-9934-26-039-1-48

\title{
СИНТАКСИЧНІ ЗАСОБИ ВЕРБАЛІЗАЦІЇ ОБРАЗУ-СИМВОЛУ ЛАБІРИНТ У СУЧАСНИХ АМЕРИКАНСЬКИХ ФЕНТЕЗІЙНИХ ТЕКСТАХ
}

\author{
Стеценко Д. В. \\ аспірантка \\ Київського наџіонального лінгвістичного університету \\ м. Київ, Украӥна
}

Уже багато століть образ лабіринту привертає увагу письменників завдяки своїм енігматичним особливостям і різноманіттю тлумачень. Лексема лабіринт бере свій початок від давньогрецького слова «labyrinthos», що означає «велика будівля $з$ заплутаними пасажами». Своє трактування слово отримало завдяки складній конструкції, в яку була закута міфічна істота Мінотавр на острові Кріт. Нідерландський лінгвіст Роберт Бекес [4] висуває теорію про походження слова labyrinthos від давнішої до-грецької лексеми laura (вузька вулиця, алея, квартал). Досі достеменно невідома етимологія слова лабіринт, що 
робить його істинне розуміння таємничим та загадковим [7]. Проте, загальноприйнятим $\epsilon$ розуміння лабіринту як дуже складного, заплутаного розташування приміщень, переходів, доріг, алей у парку тощо [7]. Тлумачення лабіринту як матеріального об'єкту є обмеженим для повного і багатопланового його розуміння. 3 плином віків лабіринт перетворився на символ, що позначає різномаїття життєвих проблем i труднощі вибору правильного рішення [8].

Дослідження лабіринту як таємниці 3 перспективи філології здійснено переважно у площині детективного жанру (Т.О. Бехта, Н. Ю. Філістова, S. Knobloch, C. Reitz, C. J. Rzepka), вивчено етимологію та семантику іменникових вербалізаторів концепту ТАСМНИЦЯ (А. Б. Калюжна, І. В. Змійова), мовні засоби відображення містичного (О. Б. Галич). Ми підходимо до аналізу цього явища як образу-символу i виявляємо стилістичні засоби його вербалізації в художньому фентезійному тексті.

Матеріалом нашого дослідження є роман антиутопія Девида Дешнера «Той, що біжить лабіринтом» (2005 р.) [5]. Як показує матеріал нашого дослідження, проходження через лабіринт героями аналізованих нами текстів асоціюється з ініціацією (просвітленням), символічним поверненням в материнське лоно, переходом через смерть до відродження, відкриттям духовного центру, а також напруженим, часто таким, що веде в безвихідь, процесом пізнання. Образ-символ лабіринт має вербальне $\mathrm{i}$ невербальне вираження в тексті.

Вербалізація образу-символу лабіринт відбувається засобом лексикосемантичних його дескрипторів та синтаксичних конструкцій. На синтаксичному рівні образ-символ лабіринт реалізується редукційними та екстенсіональними конструкціями. В аналізованих фрагментах, в яких знаходить своє вербальне вираження образ-символ лабіринт, спостерігаємо домінування таких редукційних конструкцій, як парцеляція «Thomas. Newbie. My new friend. Forget it», асиндетон «He scanned their faces, taking in each expression, judging them», еліпсис «Have you ever tried making a rope? Yes. With the ivy», а також екстенсіональних конструкцій, як-от: паралелізм «He was so lost and didn't even know his age» та анепіфора «Never go out at night. No matter what. Never» [5]. Подібні редукційні синтаксичні засоби іконічно візуалізують в уявленні читача/інтепретатора форму лабіринту і створюють атмосферу лабіринту так, що відчуваються різні його ефекти: уривчастість пасажів лабіринту, поворотів, закутень, а екстенсіональні фігури формують відчуття повторюваності патернів шляху, його звивистість та складність. 
Синтаксичний рівень є одним із магістральних для інтерпретації образу-символу лабіринт. Вибір автором тих чи інших синтаксичних структур може бути свідомим або несвідомим, проте він має безпосередній вплив на читача твору, активізує бажання зрозуміти смисл всіх тих пасажів і складнощів, а також спробувати декодувати приховані сенси. Засобом синтаксичних структур образ-символ лабіринт вербалізується як просторовий квест, який необхідно подолати для того, щоб знайти вихід із тієї чи іншої ситуації. Інтегруючись 3 іншими стилістичними фігурами мовлення синтаксис допомагає систематизувати багаторівневу, калейдоскопічну конструкцію лабіринту.

\section{Література:}

1. Арнольд И. А. Стилистика. Современный английский язык. Москва: Наука, 2002. 384 с.

2. Бройтман М. С. Ключевые знаки, организующие пространство текста романа Х. Кортасара. Вестник, серия Лингвистика. Москва, 2010. № 4. C. 25-30.

3. Кухаренко В. А. Інтерпретація тексту. Вінниця: НОВА КНИГА, 2004. $272 \mathrm{c}$.

4. Beekes R. Etymological Dictionary of Greek. Leiden Indo-European Etymological Dictionary Series. Leiden: Brill, 2010. Vol. 2. 1808 p.

5. Dashner J. The Maze Runner. Somerset: Chicken House, 2005. 371 p.

6. Halliday M. A. K., Hasan R. Cohesion in English. London, 1976. $367 \mathrm{p}$.

7. Online Etymology Dictionary. URL: https://www.etymonline.com/ word/labyrinth\#etymonline_v_1974

8. Tresidder J. The Complete Dictionary of Symbols. Chronicle Books, 2005. $544 \mathrm{p}$.

9. Volkova S. Iconicity of syntax and narrative in Amerindian prosaic texts. In Lege artis. Language yesterday, today, tomorrow. The journal of University of SS Cyril and Methodius in Trnava. Warsaw, 2018. Vol. III (1). P. 448-479. 